\title{
Perfect match: mTOR inhibitors and tuberous sclerosis complex
}

\author{
Cong Luo ${ }^{1 \dagger}$, Wen-Rui Ye ${ }^{2 \dagger}$, Wei Shi ${ }^{3}$, Ping Yin ${ }^{4}$, Chen Chen ${ }^{5}$, Yun-Bo He ${ }^{1}$, Min-Feng Chen ${ }^{1}$, Xiong-Bin Zu ${ }^{1}$ and \\ Yi Cai ${ }^{i^{*}}$ (10)
}

\begin{abstract}
Tuberous sclerosis complex (TSC) is an autosomal dominant syndrome that presents with diverse and complex clinical features and involves multiple human systems. TSC-related neurological abnormalities and organ dysfunction greatly affect the quality of life and can even result in death in patients with TSC. It is widely accepted that most TSC-related clinical manifestations are associated with hyperactivation of the mammalian target of rapamycin (mTOR) pathway caused by loss-of-function mutations in TSC1 or TSC2. Remarkable progress in basic and translational research has led to encouraging clinical advances. Although mTOR inhibitors (rapamycin/everolimus) demonstrate great potential in TSC management, two major concerns hamper their generalized application. One is the frequent manifestation of adverse events, such as stomatitis, infections, and menstrual disorders; and the other is the poor response in certain patients. Thus, indicators are required to effectively predict the efficacy of mTOR inhibitors. Herein, we have summarized the current utilization of mTOR inhibitors in the treatment of TSC and focused on their efficacy and safety, in an attempt to provide a reference to guide the treatment of TSC.
\end{abstract}

\section{Highlights}

Hyperactivation of mammalian target of rapamycin (mTOR) is essential in thepathogenesis of tuberous sclerosis complex (TSC) and can serve as a therapeutictarget.

mTOR inhibitors have shown considerable success in multiple clinical trials for the treatment of TSC, including neurological, pulmonary, cardiac, renal, and cutaneousphenotypes.

mTOR inhibitors are associated with adverse events, which should be consideredduring the management of TSC. Indicators to predict mTOR inhibitor efficacy are required to select patients whoare likely to benefit from such therapy. Keywords: Tuberous sclerosis complex (TSC), mTOR inhibitors, Efficacy, Adverse events, Precision medicine

\footnotetext{
*Correspondence: cai-yi@csu.edu.cn

${ }^{\dagger}$ Cong Luo and Wen-Rui Ye have contributed equally

1 Department of Urology, Disorders of Tuberous Sclerosis Complex (TSC) Multidisciplinary Team, National Clinical Research Center for Geriatric Disorders, Xiangya Hospital, Central South University, Changsha City 410008, Hunan Province, People's Republic of China

Full list of author information is available at the end of the article
}

\section{Introduction}

As an autosomal dominant disorder, tuberous sclerosis complex (TSC) has an incidence of 1 in 6000-10,000 individuals [1]. It involves multiple human systems and presents with diverse and complex clinical features that result in different pathologies. For instance, TSC can lead to widely distributed hamartomas in multiple organs including the brain, lungs, heart, kidneys, and skin. Moreover, TSC can cause disabling neurological original author(s) and the source, provide a link to the Creative Commons licence, and indicate if changes were made. The images or other third party material in this article are included in the article's Creative Commons licence, unless indicated otherwise in a credit line to the material. If material is not included in the article's Creative Commons licence and your intended use is not permitted by statutory regulation or exceeds the permitted use, you will need to obtain permission directly from the copyright holder. To view a copy of this licence, visit http://creativecommons.org/licenses/by/4.0/. The Creative Commons Public Domain Dedication waiver (http://creativecommons.org/publicdomain/zero/1.0/) applies to the data made available in this article, unless otherwise stated in a credit line to the data. 
disorders such as epilepsy and TSC-associated neuropsychiatric disorders (TANDs).

These various manifestations with different penetrance are summarized in Fig. 1. Epilepsy is the most common disorder of the nervous system that affects $80 \%-90 \%$ of patients with TSC. It often starts in infancy and manifests as infantile spasms [2]. Although both subependymal nodules (SEN) and subependymal giant cell astrocytomas (SEGA) are space-occupying lesions growing beneath the ependyma, the probabilities of their occurrence are considerably different. Briefly, about $80 \%-90 \%$ of patients with TSC present with SEN, as determined using brain magnetic resonance imaging (MRI), whereas only $10 \%-$ $15 \%$ of patients develop SEGA [3]. A recent growing concern among clinicians is the high incidence (approximately $90 \%$ ) of TANDs in the TSC population, which include autism spectrum disorder (ASD), attention deficit hyperactivity disorder (ADHD), depression and anxiety, intellectual disability, and specific learning disabilities [4]. The most common morphology of TSC in the lung is lymphangioleiomyomatosis (LAM), a progressive condition characterized by cystic lung destruction with diffuse pulmonary infiltration of smooth muscle-like cells. On a cautionary note, it occurs in up to $80 \%$ of female patients without any clinical symptoms. Overt clinical symptoms including shortness of breath, fatigue and chest pain, or even respiratory failure, occur in only $5 \%-10 \%$ of the general population (including males) [5]. In contrast, multifocal micronodular pneumocyte hyperplasia $(\mathrm{MMPH})$ affects males and females equally and has an incidence of $40 \%-60 \%$ [6]. MMPH causes small nodular lung deposits of type II pneumocytes that rarely progress

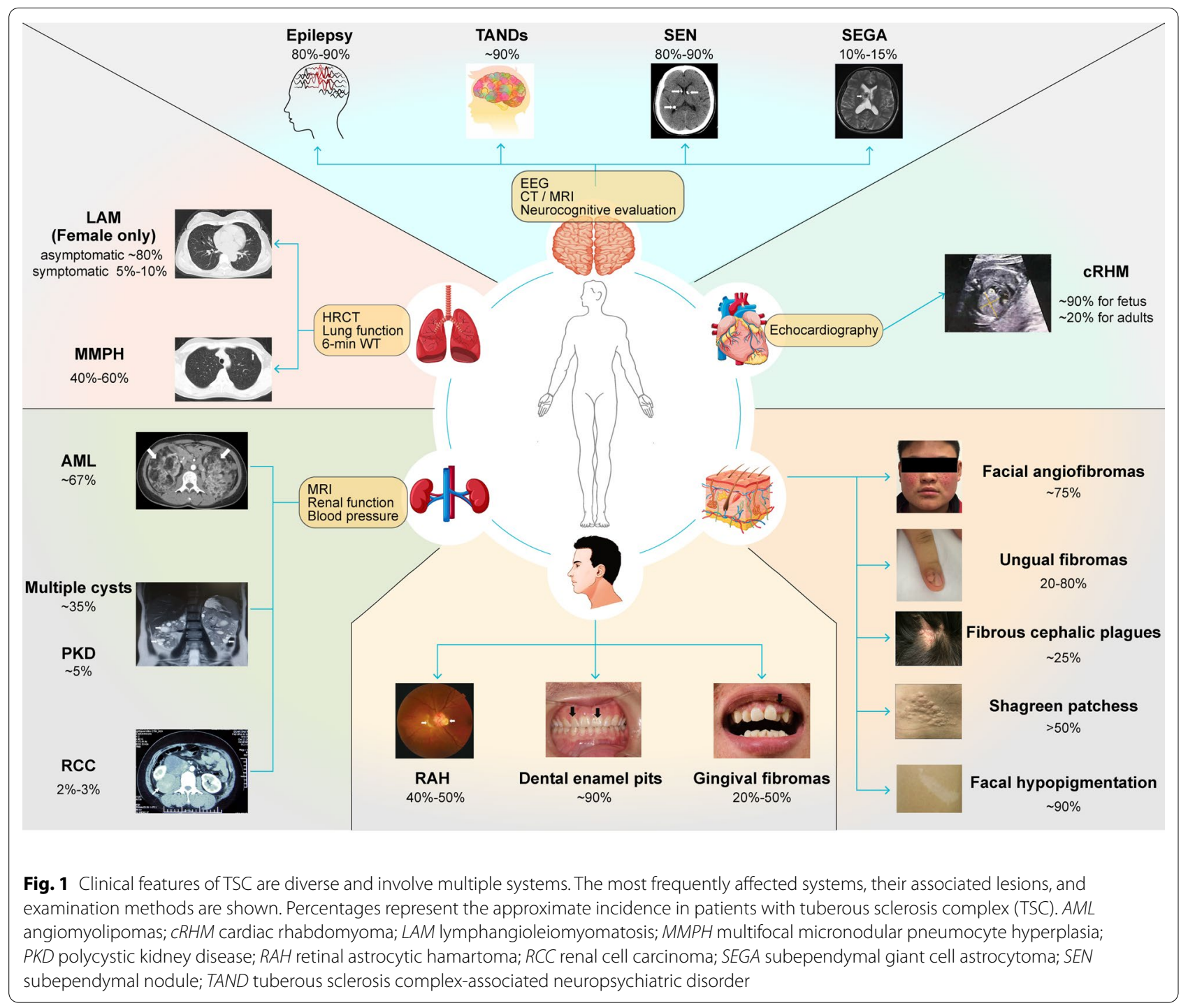


to symptomatic disease. Cardiac rhabdomyoma (cRHM) is a common benign cardiac tumor in patients with TSC that is found in $90 \%$ of intrauterine fetuses; Unlike other TSC symptoms, most cRHMs subside spontaneously in early childhood [3]. However, it may also re-grow or occur de novo in adolescence, especially in girls [7]. Generally, approximately $20 \%$ adults still carried cRHM. Angiomyolipomas (AML) and simple multiple cysts, the two most common renal lesions of TSC, are mostly found in adult patients and accounts for $67 \%$ and 35\% of cases, respectively [8-10]. More severe renal manifestations include polycystic kidney disease (PKD) and renal cell carcinoma (RCC), although they are also rarer with an incidence of $5 \%$ and $2 \%-3 \%$, respectively $[11,12]$. Skin lesions including facial angiofibromas (75\%), ungual fibromas (20\%-80\%), fibrous cephalic plaques (25\%), shagreen patches (>50\%), and focal hypopigmentation $(90 \%)$ [3] develop in almost all patients with TSC [13]. Besides, retinal astrocytic hamartomas (RAH) were observed in $40 \%-50 \%$ of patients with TSC, especially in those carrying gene mutations [14]. Oral manifestations include gingival fibromas and dental enamel pits. The incidences are $20-50 \%$ and $90 \%$, respectively [14]. The prognosis in individuals with TSC depends on the severity of their symptoms.

TSC is associated with significant involvement of human systems and can also lead to patient death due to accompanying symptoms. Specifically, the common causes of death include status epilepticus, bronchopneumonia, brain tumors, renal complications, pulmonary LAM, and neonatal heart failure caused by CRHM. Therefore, there is an urgent requirement to identify find safe and effective treatment approaches.

In the past, the management of TSC was unintegrated. For example, antiepileptic drugs were used only to treat epilepsy, surgery was used for SEGA and renal AML, and dermatological treatment was used in the management of skin lesions. With the gradual recognition that hyperactivation of the mammalian target of rapamycin (mTOR) signaling pathway plays an important role in the multisystem involvement of TSC, the efficacy of mTOR inhibitors for the treatment of TSC has been increasingly investigated (Table 1). mTOR inhibitors have shown great potential in the treatment of TSC. In addition to their routine use in the management of renal AML and SEGA, they also have a mitigating effect on other TSC-related manifestations such as epilepsy and skin lesions. However, few articles have systematically summarized the efficacy and safety of mTOR inhibitors for the treatment of TSC. A recent article systematically summarized only the adverse events (AEs) of everolimus based on the TOSCA cohort [15]. Herein, we discussed the role of the activation of the mTOR signaling pathway in the pathogenesis of TSC, and focused on both efficacy and safety of mTOR inhibitors in the treatment of various clinical manifestations of TSC. This has not been systematically reported and will provide an important and comprehensive reference for the clinical use of mTOR inhibitors in the context of TSC.

\section{Role of mTOR signaling pathway activation in the pathogenesis of TSC}

TSC is believed to develop from the pathogenic variants of the TSC1 gene and more commonly the TSC2 gene, which encode hamartin and tuberin, respectively $[16,17]$. The encoded proteins physically interact with high affinity to form a heterotrimeric complex, termed the TSC protein complex, with the TBC1 domain family member 7 (TBC1D7) [18, 19]. After the discovery of TSC1, TSC2, and the TSC protein complex, substantial progress has been made toward understanding the pathogenesis of TSC. The most widely accepted mechanism is that TSC1/TSC2 mutations inactivate the TSC protein complex, leading to a loss of inhibitory effect on the mTOR pathway, which mediates cell growth and metabolism in response to alterations in growth factors, cellular energy, and nutrient status (Fig. 2) [20]. Under normal conditions, growth factors stimulate the PI3K (phosphatidylinositol 3-kinase) and Ras-MAPK (mitogen-activated protein kinase) pathways, thereby inhibiting the TSC protein complex and activating mTOR signaling [21-23]. mTOR is a conserved serine-threonine protein kinase that regulates cell growth and proliferation through two distinct multimeric complexes: mTOR complex 1 and 2 (mTORC1 and mTORC2, respectively). mTORC1 integrates multiple upstream signaling pathways, including inputs from growth factors, amino acids, energy status, and cellular stressors such as hypoxia. It functions by phosphorylating two effector molecules, ribosome S6 protein kinase (p70S6K) and 4E-binding protein 1 (4E$\mathrm{BP} 1)$, to promote cell growth and proliferation. Specifically, the phosphorylation of p70S6K activates ribosomal protein S6, thereby increasing ribosomal recruitment and protein translation that is essential for cell expansion [24]. Meanwhile, the phosphorylation of 4E-BP1 can selectively promote the translation of mRNAs that support the survival of tumor cells during starvation [25-27].

Normally, mTORC1 can be activated by the RAS homolog enriched in brain (Rheb) by binding to guanosine- $5^{\prime}$-triphosphate (GTP). A recent study has found that the TSC protein complex inhibits Rheb function via the GTPase-activating protein (GAP) domain near the carboxy terminal of tuberin [28]. Constitutively active Rheb hyperactivates mTORC1 in the absence of a functional TSC protein complex, leading to extensive metabolic reprogramming, including enhanced lipid, 


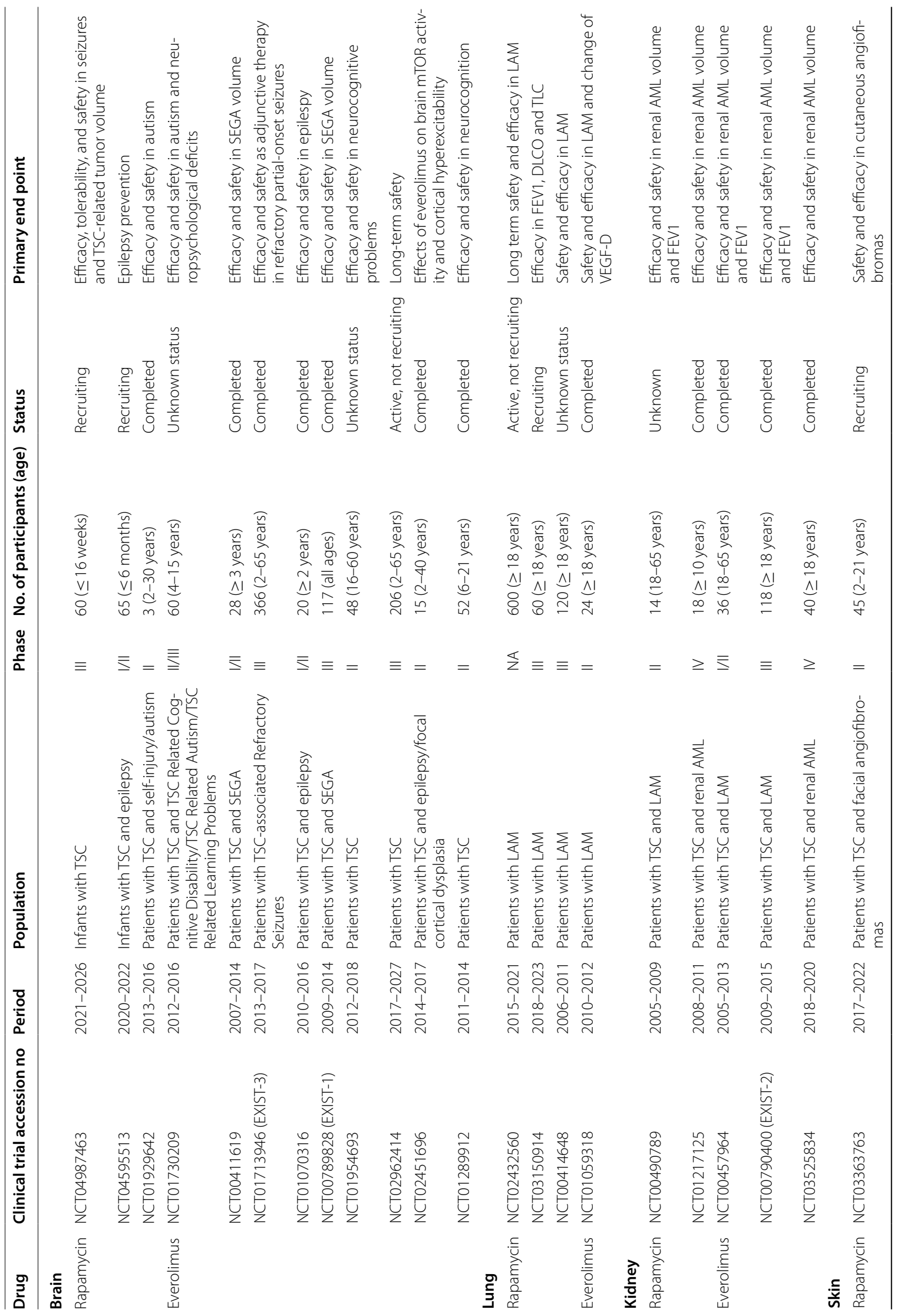




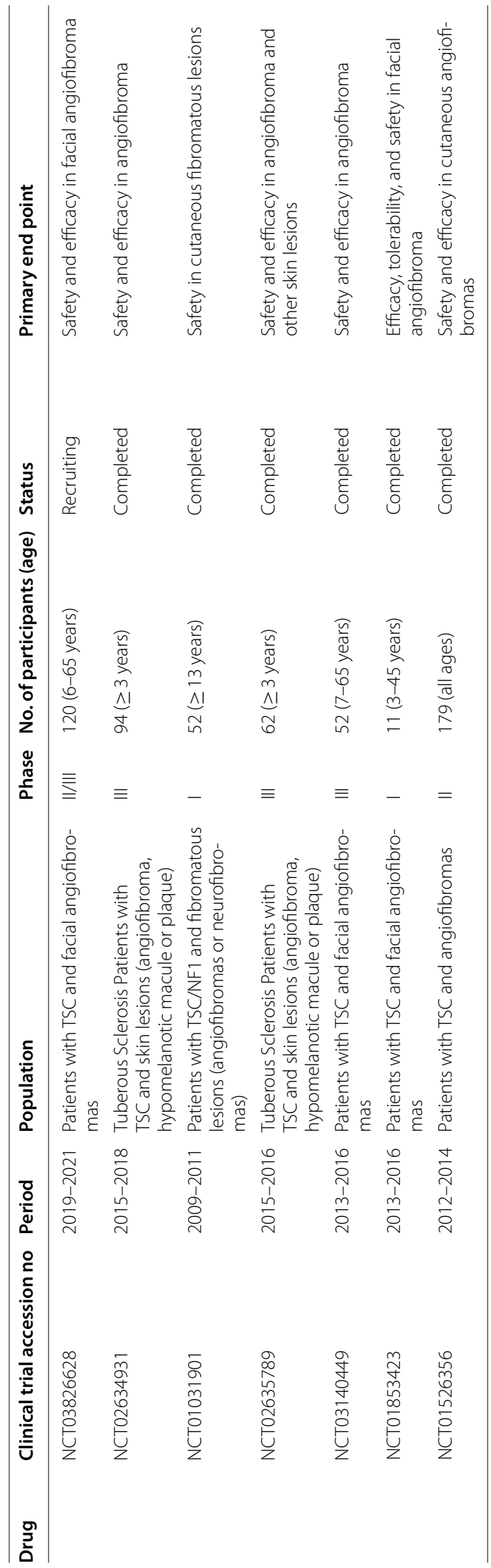




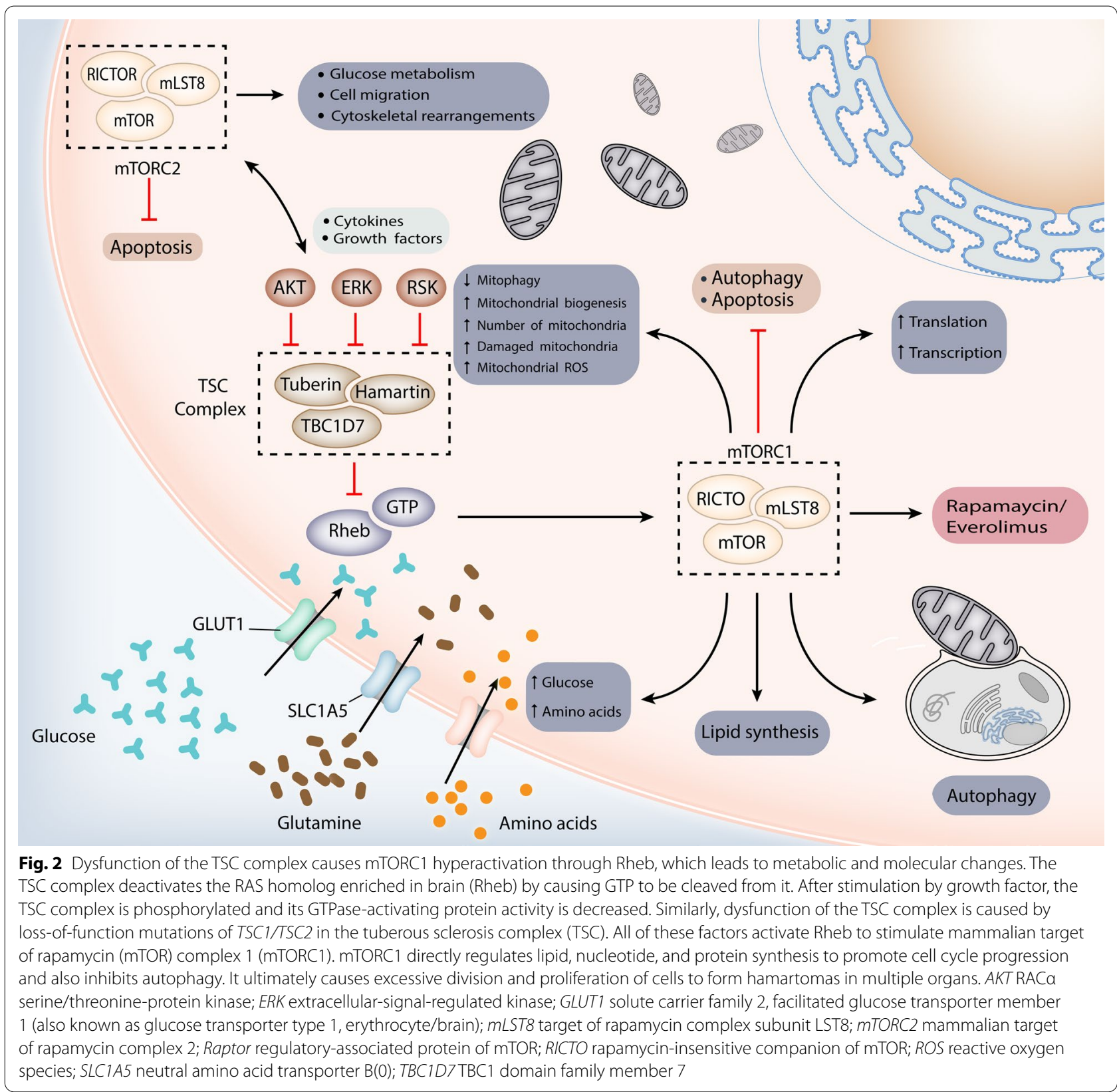

nucleotide, and protein synthesis and the inhibition of autophagy $[18,19,29]$. This reprogramming leads to vulnerabilities in induced cell death under specific conditions, such as in nutrient-deficient media. Moreover, the altered metabolism prone to anaerobic glycolysis is also one of the identified tumor hallmarks. Therefore, mTORC1 hyperactivation may partially explain the formation of TSC-associated solid tumors.

In the central nervous system, the mTOR pathway is involved in neuronal migration and cortical lamination, which are essential for the regulation of arborization of dendrites and determination of neuronal polarity in the early postnatal cerebral cortex [30]. mTORC1 hyperactivation and enhanced downstream activity induced by TSC1/TSC2 mutations can lead to neuronal dysfunctions, as well as dysregulation or impairment of biological processes such as axon regulation and guidance, dendritic morphogenesis, synapse formation, and adaptation. Therefore, dysregulation of the mTOR pathway in patients with TSC also causes defects in these fundamental processes leading to abnormalities in neural circuit formation and activity-dependent plasticity, which in 
turn trigger epilepsy and TANDs. Specifically, upregulation of the mTOR pathway results in abnormal dendritic protein synthesis, reduced or deformed dendritic spines, and long-term depression mediated by alterations in the postsynaptic glutamate receptor [31-33]. Additionally, these synaptic abnormalities are considered to cause defects in learning, memory, and adaptability in patients with TSC having an ASD phenotype [34-36]. Moreover, changes in synaptic or cellular electrical properties may lead to abnormalities in neuronal excitability. The decrease in $\gamma$-aminobutyric acid (GABA)-ergic inhibition and increase in glutamatergic excitation are associated with higher epilepsy susceptibility in TSC populations and have the potential to elicit cognitive impairment [37-39].

With respect to TSC-associated skin lesions, the most frequently observed focal hypopigmentation has been suggested to be associated with mTOR. JóźWiak and Galus reported the inhibitory effect of mTOR hyperactivation on the microphthalmia-associated transcription factor in TSC, a master regulator of melanogenesis [40]. Hoet et al. proposed that mTORC1 inhibition promoted melanogenesis by increasing the transcription of melanogenic enzymes and the formation of mature melanosomes [41]. In a nutshell, hyperactivated mTORC1 suppresses melanogenesis, resulting in focal hypopigmentation in patients with TSC.

In summary, we have captured a trail of mTORC1 hyperactivation underlying the pathogenesis of TSC, confirming the critical role of this pathway in TSC, and highlighting its potential as a therapeutic target.

\section{mTOR inhibitors in the treatment of TSC}

The currently recognized mTOR inhibitors against TSC include sirolimus and everolimus. Sirolimus, also known as rapamycin, was isolated in 1973 from soil samples in Easter Island [42]. Everolimus is a sirolimus derivative obtained by the addition of an ethyl ester group. Both compounds bind to and inhibit mTORC1, resulting in the allosteric dissociation of its cofactor rapTOR (TOR regulation-related protein, also known as FKB12), which is necessary for mTORC1 activity [43]. However, everolimus demonstrates better absorption, higher oral bioavailability, more rapid achievement of steady-state blood concentration after administration, and faster elimination after withdrawal compared with sirolimus [44-46]. Discoveries related to TSC pathogenesis have led to the hypothesis that the altered metabolism of cells due to mTORC1 hyperactivation may provide therapeutic opportunities. Specifically, the inhibition of mTORC1 using allosteric inhibitors restores metabolic homeostasis in abnormal cells, thereby reversing TSC-associated clinical manifestations [47]. Herein, we focus on the use of
mTOR inhibitors in the treatment of TSC, especially the various related manifestations.

\section{Brain \\ Subependymal giant cell astrocytomas}

In 2006, the first case series was published in which five patients with TSC having SEGAs were treated using open-label rapamycin. The tumor volume was significantly reduced in all patients. Given the regrowth of SEGA after drug discontinuation at the patient's request, rapamycin treatment was restarted, which led to reshrinking of the tumor [48]. The mTOR inhibitor everolimus, a rapamycin derivative, shows better pharmacokinetics. The first prospective clinical trial of everolimus in the treatment of SEGA $(n=28)$ demonstrated $\mathrm{a} \geq 30 \%$ volume reduction in SEGA in 21 patients and $a \geq 50 \%$ reduction in nine patients [49]. Based on these results, a complete clinical plan (EXIST-1) was developed to evaluate the efficacy and safety of everolimus in the treatment of TSC-related SEGA. In this multicenter, randomized, placebo-controlled phase III trial, 27 (35\%) patients in the everolimus group experienced $a \geq 50 \%$ reduction in SEGA volume compared with no reduction in those in the placebo arm [50]. Furthermore, more patients achieved $\mathrm{a} \geq 50 \%$ reduction in SEGA volume at long-term follow-up with blood concentrations of $5-15 \mathrm{ng} / \mathrm{mL}$, and the efficacy of everolimus in reducing primary SEGA volume was maintained [51, 52]. Notably, SEGA rebound after everolimus discontinuation was observed in these clinical trials, suggesting that the treatment of TSC-associated SEGA requires continuous pharmacological intervention. Thus, in October 2010, the US Food and Drug Administration (FDA) approved everolimus to treat TSC-associated SEGA of all ages and recommended long-term treatment.

\section{Refractory epilepsy}

Refractory epilepsy is a common clinical manifestation in patients with TSC and can progress to status epilepticus, which is life-threatening [53]. TSC-associated epilepsy mostly responds poorly to traditional antiepileptics. Inspiringly, early clinical trials show that mTOR inhibitors reduce the frequency of refractory epilepsy and bring about tumor- and nodule-volume reduction [49, 51]. There was, however, a significant difference in the frequency of baseline epilepsy between the control and treatment groups, as most of these studies analyzed the control of epilepsy as a secondary endpoint. This aspect, combined with the fact that a large proportion of patients did not present with epilepsy at the beginning of treatment, greatly reduced the credibility of the results. Subsequently, researchers conducted a prospective clinical trial aimed at the treatment of refractory epilepsy with 
everolimus [54]. After 3 months of treatment, 17 (85\%) participants reported a reduction in epilepsy frequency and $12(60 \%)$ reported $a \geq 50 \%$ reduction in frequency from baseline. Additionally, a significant reduction in the duration of epilepsy episodes and improvements in parent-reported behavior and quality of life were reported. To further confirm this benefit, a phase III clinical trial (EXIST-3) was conducted in a large sample population to assess the efficacy and safety of everolimus as adjuvant therapy in patients with TSC having refractory focal-onset epilepsy [55]. Briefly, 366 participants aged 2-65 years were randomly divided into a placebo arm $(\mathrm{n}=119)$, low-dose everolimus arm (blood concentration: $3-7 \mathrm{ng} / \mathrm{mL} ; \mathrm{n}=117$ ), or a high-dose everolimus arm (blood concentration: $9-15 \mathrm{ng} / \mathrm{mL} ; \mathrm{n}=130$ ). The primary endpoint was the proportion of patients achieving $a \geq 50 \%$ reduction in epilepsy frequency. The response rates were $15.1 \%, 28.2 \%$, and $40.0 \%$ in the placebo, lowdose everolimus, and high-dose everolimus arms, respectively, which rigorously demonstrated the excellent remission efficacy of everolimus in TSC-related refractory epilepsy. Meanwhile, this was the first evidencebased study to propose the superiority of high-dose mTOR inhibitors over the low-dose ones. Nonetheless, it was found that patients treated with low-dose everolimus may achieve outcomes similar to those treated with high doses after prolonged treatment. Thus, this clinical trial facilitated the progression of the FDA approval of everolimus as an adjuvant treatment for TSC-associated epilepsy. Clinical practice has demonstrated that everolimus can reduce the dose of antiepileptic drug combinations in the treatment of TSC-associated epilepsy. Furthermore, everolimus can be used as monotherapy to control epilepsy in certain patients.

Although everolimus demonstrates strong efficacy, patients with poor economic conditions tend to choose the more affordable rapamycin as routine medication. Several researchers have investigated the efficacy of rapamycin in controlling TSC-associated epilepsy and found a $41 \%$ decrease in epilepsy frequency compared with the standard-of-care treatment in pediatric patients [56]. More recently, a Chinese cohort with 91 pediatric individuals with TSC reports a response rate of $78.0 \%$, and even $47.2 \%$, of patients achieved epilepsy-free [57]. These results suggest that rapamycin can be used as an alternative to everolimus in the adjuvant treatment of TSC-associated epilepsy when necessary.

\section{White matter diffusion}

Studies have described abnormalities in normal-appearing white matter (NAWM) in TSC based on diffusion tensor imaging (DTI), which included decreased fractional anisotropy (FA) or increased mean diffusivity measures within tubers surrounding the subcortical white matter [58-60]. Subgroup analyses based on the DTI data from phase I/II clinical trials evaluating the efficacy of everolimus in the treatment of SEGA reveal significant changes in FA and radial diffusion rate after everolimus treatment in patients with TSC [61]. These findings indicate a pharmacological modification over the TSC genetic defects in the brain and provide the possibility that mTOR inhibitors may have a therapeutic effect on TSC-associated mental ailments.

\section{TSC-associated neuropsychiatric disorders}

The treatment of TANDs has always been challenging due to their complex pathogenesis. In an open epilepsy trial, Krueger et al. reported a statistically significant improvement in adaptive social behavior, behavioral problems, and insecurity/anxiety compared with the corresponding presentation at baseline. The quality-of-life assessment for epileptic children revealed similar improvements in many areas, including attention, behavior, social interaction and activities, and the overall quality of life [54]. However, it is uncertain whether these changes are secondary to or independent of epilepsy control.

Therefore, a prospective phase II study was conducted to evaluate the efficacy of everolimus in treating TANDs. A total of 47 children age 6-21 years were randomized in a 2:1 ratio of everolimus:placebo for 6 months [62]. It was found that everolimus treatment failed to improve TANDs in this study. A recent study enrolled 60 children aged 4-17 years with TSC and IQ $<80$, learning disabilities, special schooling or autism, and no refractory epilepsy, to investigate whether everolimus (blood concentration: 5-10 $\mathrm{ng} / \mathrm{mL}$ ) could improve intellectual disability, autism, and other neuropsychological deficits [63]. Similarly, no positive results were found. We cannot arbitrarily conclude that everolimus does not mitigate TANDs, as some clinical trials are still underway and have not yet published their findings. For example, the trial of everolimus and neurocognition in TSC (NCT01289912), the TRON study (NCT01954693), the RAPT study (NCT01929642), and the phase II/III Dutch RAPIT study (NCT01730209) are still ongoing.

\section{Lung \\ Lymphangioleiomyomatosis}

As a secondary endpoint, a pilot study of rapamycin for AML showed improvement in spirometric measurements and persisted gas trapping in some patients with LAM [64], indicating the potential of mTOR inhibitors in the treatment of TSC-associated LAM. Thereafter, a randomized placebo-controlled trial of rapamycin was conducted in adult patients with moderate LAM, and significant remission of the loss of lung function and an 
improvement in forced vital capacity, quality of life, and functional performance was reported. The lung function deteriorated again and paralleled that in the placebo group after the discontinuation of rapamycin [65]. Therefore, lifelong continuous treatment with rapamycin is recommended. Another similar study reported an improvement and stabilization of lung function and a reduction in the extent of chylous effusions and LAM after treatment with rapamycin [66]. Based on these results, the FDA approved rapamycin in 2015 for the treatment of TSC-associated LAM.

Considering the more optimal pharmacokinetics of everolimus, a study explored the efficacy of everolimus in 24 adult women with LAM and found that lung function and exercise capacity could be improved by everolimus treatment [67]. In general, mTOR inhibitors retard the deterioration in lung function in most women with LAM; however, whether they can prevent the progression of LAM is still unclear.

\section{Multifocal micronodular pneumocyte hyperplasia}

As MMPH is rarely clinically symptomatic, there are only a few studies that have focused on the medical treatment of MMPH. A recent study first reported a significant shrinkage of MMPH was achieved in a 25-year-old man after treatment with mTOR inhibitor [68]. Although this is only a case report, the findings lay a foundation for follow-up studies focusing on the therapeutic effects of mTOR inhibitors in MMPH.

\section{Heart}

\section{Cardiac rhabdomyoma}

Despite the generally favorable outcomes and spontaneous regression, multiple or large cRHMs may result in heart failure or cardiac arrhythmias that require intervention. A meta-analysis summarized the use of mTOR inhibitors in the treatment of cRHM in pediatric patients, most of which were neonates [7]. It reported that the clinical symptoms improved in $90.9 \%$ of patients after treatment and the size of cRHM was reduced by $95.1 \%$. Although some cRHMs recurred after withdrawal of the mTOR inhibitor, clinical symptoms were mostly not observed. However, it is important to note that most of the included studies were case reports. A lack of randomized or large cohort studies reduces the validity of the estimated effects. Moreover, it is difficult to determine whether the reduction was due to the efficacy of the mTOR inhibitor or spontaneous regression, given the inherent nature of cRHM. Findings from a recent case series provide the answer. This case series evaluated the tumor regression in four neonates with cRHM after everolimus treatment and compared it with natural regression. Tumor regression after everolimus treatment was nearly 12 times faster compared with the control, confirming the efficacy of everolimus in cRHM [69]. Thus, everolimus may be a suitable treatment option for patients who are symptomatic and are at potential risk for serious cardiac events due to cRHM-related obstruction [70]. More definitive evidence is needed for asymptomatic patients to establish that everolimus use confers significant benefits.

\section{Kidneys \\ Renal angiomyolipomas}

Renal AML contributes to chronic kidney disease (CKD) and intrarenal hemorrhage and is a common cause of TSC-related mortality. The traditional treatment of renal AML, including embolization or (partial) nephrectomy, has significant disadvantages. Collateral damage to normal renal tissues may aggravate the risk of renal dysfunction $[71,72]$ and lead to a high risk of postembolization recurrence [72-74]. Therefore, new therapies are warranted. With an increase in the understanding of the pathogenesis of TSC, several attempts have been initiated for the use of mTOR inhibitors in the treatment of renal AML. The clinical response of renal AML to an mTOR inhibitor was first reported in 2006. AML was significantly reduced in a 19-year-old patient after treatment with rapamycin and his tumor relapsed after drug discontinuation. Upon reinitiating rapamycin, the tumor shrank again [75]. The CAST trial was the first prospective clinical trial that evaluated the therapeutic effects of rapamycin in 25 patients with AML aged 18-65 years. The blood concentration was controlled in $1-15 \mathrm{ng} / \mathrm{ml}$, which was adjusted according to the response. After 12 months of treatment, the mean AML volume decreased to $53.2 \% \pm 26.6 \%$ of the baseline value. However, the mean volume increased to $85.9 \pm 28.5 \%$ of the baseline value at the 12th month after rapamycin withdrawal [64], warranting continued treatment. Similar results have been reported by several multicenter phase II clinical trials [76-79]. Moreover, most shrinkage occurred during the first year of treatment before the stabilization of AML in continued therapy.

A randomized phase III trial (EXIST-2) with a large sample size was initiated after the discovery of everolimus to evaluate its efficacy in the treatment of TSCassociated AML for adult patients [80]. In this trial, the response rate of AML to everolimus was $42 \%$ compared with 0 with placebo, demonstrating the remarkable efficacy of everolimus in treating AML. Another study focusing on the short-term use of everolimus reported that the mean reduction in AML volume was $56.47 \pm 23.32 \%$ within 12 weeks, and that drug discontinuation resulted in regrowth [81]. Moreover, the efficacy and safety of everolimus in the treatment of renal AML 
have also been confirmed in patients aged $<18$ years with the blood concentration of 5-15 $\mathrm{ng} / \mathrm{mL}$ [82].

Considering the encouraging efficacy of mTOR inhibitors, the International Tuberous Sclerosis Complex Consensus Conference held in 2012 recommended mTOR inhibitors as the first-line treatment for renal AML with a diameter $\geq 3 \mathrm{~cm}$, even if patients did not present with any clinical symptoms [71].

\section{Cystic disease}

As the TSC2 and PKD1 genes are adjacently located, TSC2 mutation is sometimes accompanied partially or completely by PKD1 mutation, which can cause PKD, also known as the contiguous gene syndrome. The renal phenotype in these patients tends to be more severe with premature progression to renal failure [11, 83]. Besides, some TSC patients suffer simple cytic disease without $\mathrm{PKD}$ gene mutation. However, safe and effective therapies are currently unavailable for TSC-associated renal cystic disease, although a study has reported that rapamycin may have some therapeutic effect. This study enrolled 15 pediatric patients with known renal cystic disease and TSC. However, these patients have not been detected for PKD gene, so it is impossible to distinguish between the contiguous gene syndrome and simple cytic disease in TSC. Generally, for TSC-associated renal cystic disease, the results showed a decrease in the sum of cyst diameters of 15 patients, a decrease in the total cyst volume in 14 patients, and a $72.1 \%$ decrease in the cyst number [84]. The sample size of this study is relatively small. Therefore, whether mTOR inhibitors are effective in TSC-associated renal cystic disease requires further investigation.

\section{Renal cell carcinoma}

Treatment strategies for TSC-associated RCC are similar to those used for general RCC and include surgery, chemoradiotherapy, and immunotherapy. Everolimus is currently approved for the treatment of advanced RCC after failure of initial therapy with tyrosine kinase inhibitors. However, to date, there is only one case report that shows that a 47-year-old patient with TSC-associated metastatic RCC continued to benefit from everolimus over a 2-year follow-up [85]. Thus, additional evidence from cohort studies is required to obtain further therapeutic insights into TSC-associated RCC.

\section{Skin}

\section{Facial angiofibromas}

TSC-associated facial angiofibromas have previously been treated using laser surgery, cryotherapy, resurfacing, or similar approaches. However, pain, scarring, and lesion recurrence cannot be avoided [86-88]. Initial findings from EXIST-1 and EXIST-2 reported a partial response of skin lesions during treatment with systemic mTOR inhibitors [50,80], which was further confirmed based on the long-term follow-up of oral everolimus [89]. However, treatment with systemic mTOR inhibitors is associated with serious AEs; thus, they are not approved solely for the treatment of skin lesions. In 2012, the first study of topical rapamycin for the treatment of TSC-associated facial angiofibromas demonstrated considerable efficacy and safety in 28 patients aged $>13$ years (blood concentrations $<1.0 \mathrm{ng} / \mathrm{mL}$ ), wherein $73 \%$ of patients treated with topical rapamycin versus $38 \%$ treated with placebo reported a subjective improvement in angiofibromas [90]. Similar results were obtained in another left-right comparative study, which enrolled 11 patients aged $<10$ years [91]. Thus, the 2012 International Tuberous Sclerosis Complex Consensus Conference included topical rapamycin into their treatment recommendations for angiofibromas [71]. Subsequently, several clinical trials and meta-analyses reported similar results and proposed an optimal drug concentration of $0.2 \%$ [92-95]. Besides, more studies also reported that topical rapamycin is safe and effective in pediatric patients. Younger children tend to respond better, which may be attributed to the more prominent vascular components of newly developed facial angiofibromas, as vascular components elicited a better response to rapamycin than older facial angiofibromas $[96,97]$. Therefore, early treatment initiation is recommended. A randomized clinical trial recently demonstrated rapamycin-calcitriol ointment as a clinically beneficial and safe treatment option for the treatment of facial angiofibroma [98]. The advantages include a more rapid improvement of erythema, a more effective reduction in papule elevation, and longer control of the condition after drug discontinuation compared with that achieved using rapamycin alone.

\section{Focal hypopigmentation}

TSC-associated focal hypopigmentation is resistant to conventional treatment in dermatology. Previous studies have reported that rapamycin upregulates microphthalmia-associated transcription factor in B16 and MNT-1 melanoma cells, implying that rapamycin may be potentially effective in treating focal hypopigmentation [99, 100]. Subsequent to a case report showing focal hypopigmentation recovery in two pediatric patients with TSC after treatment with topical rapamycin [101], a prospective trial of topical rapamycin (drug concentration: $0.2 \%$ ) in the treatment of focal hypopigmentation was conducted, which enrolled 6 patients aged 3-33 years. The findings not only demonstrated the efficacy and safety of topical rapamycin for TSC-associated focal hypopigmentation but also confirmed that its efficacy was due to improved melanogenesis in TSC melanocytes [102]. 
However, this study had a small sample size of six patients and more evidence is required to further validate its efficacy and safety and provide better clinical guidance.

\section{Adverse effects}

Stomatitis is the most common AE of mTOR inhibitors with an incidence of approximately $70 \%[50,55,80,103]$. However, most stomatitis events were grade $1 / 2$ and self-limiting, which did not affect the continuation of the mTOR inhibitor. Maintenance of good oral hygiene, using a buffer mixed with mTOR inhibitor, and gargling with sucralfate or topical steroids can suitably control mild stomatitis [43]. Stomatitis may be severe in some cases, but is generally reversible by dose reduction or temporary discontinuation [104].

Infection is another common AE of mTOR inhibitors that is characterized by pyrexia, diarrhea, nasopharyngitis, and upper respiratory tract infections [46, 51, 77]. Although these AEs are often mild, severe cases have also been reported. For example, four patients died during the EXIST-3 study, among whom two succumbed to infection (pneumonia and septic shock) [55]. In addition to the broad immunosuppressive phenotype resulting from the use of mTOR inhibitors, another important reason is that patients often have difficulty expectorating respiratory secretions due to concomitant intellectual disability or pseudobulbar palsy, thereby increasing the risk of respiratory infections $[105,106]$. Thus, mTOR inhibitors can be continued in a clinical setting for mild infections; however, they should be discontinued if the severity of the infection increases.

Of the non-infectious AEs, menstrual irregularity is the most common. Among women $\geq 13$ years of age who received everolimus, 3 (37.5\%) in EXIST-1 and 7 (13.5\%) in EXIST-2 developed secondary amenorrhea [50, 80]. Half of them recovered spontaneously whereas the other half resumed normal menstruation after progesterone administration. A meta-analysis reported that 43 (38.4\%) patients experienced at least one menstrual irregularity. Amenorrhea and menstrual irregularity occurred in $24.1 \%$ and $17.0 \%$ of patients, respectively, and seven patients experienced grade $3 / 4$ amenorrhea [107]. Thus, it is necessary to monitor this $\mathrm{AE}$ in female patients of child-bearing age.

There are some less common AEs apart from the ones described. First, skin toxicity has been reported during therapy with mTOR inhibitors and typically presents as maculopapular or acneiform rashes [104]; its incidence in EXIST-1 and EXIST-2 was $12 \%$ and $22 \%$, respectively $[50,80]$. These skin reactions are also usually mild and self-limiting. Topical steroids are prescribed when necessary. Second, rapamycin and everolimus can significantly increase serum lipid levels by reducing lipoprotein lipase activity [104, 108]. Mild/moderate hyperlipidemia can be treated solely by dietary intervention, whereas severe hyperlipidemia may require a dose reduction of rapamycin and everolimus and/or additional hypolipidemic medications. Lastly, hyperglycemia and myelosuppression may occur during mTOR inhibitor therapy [104]. Hyperglycemia is not clinically significant in most patients; however, strict glycemic control is required in patients with pre-existing diabetes mellitus. Myelosuppression caused by mTOR inhibitors is usually minor and reversible. If it occurs, the dosing of mTOR inhibitors should be adjusted, or these drugs should either be completely withdrawn or replaced. Proteinuria is another important mTOR inhibitor-associated AE [109], which has previously been reported in small single-arm studies with sirolimus [77, 78], A recent large sample study reported that everolimus can increase the incidence of proteinuria,which was mostly Grade $1 / 2$ in severity, with Grade 3 proteinuria reported in only two patients [110]. In practice, if proteinuria is $>1 \mathrm{~g} /$ day and rising progressively, the dose of mTOR inhibitors should be adjusted (reduced or temporarily suspended until proteinuria is $<1 \mathrm{~g} /$ day).

In general, the management of AEs mainly includes dose reduction or temporary cessation [111]. Mild (grade $1 / 2$ ) AEs usually do not require dose adjustment. When a reduction is required, a dose of $50 \%$ of the original dose is recommended. For dose reduction below the minimum available intensity, alternate-day administration should be considered. If an $\mathrm{AE}$ persists or relapses, the treatment should be interrupted for 3-14 days (or until the AEs drop to $\leq$ grade 2) and restarted at a lower dose. Dose interruption/reduction can help ameliorate AEs while allowing for continued therapeutic benefits. For example, dose interruption/reduction was necessary for $71 \%$ of patients in EXIST-2, wherein approximately one-third of the dose was maintained below the initial dose of $10 \mathrm{mg} /$ day [80].

\section{Indicators to predict the efficacy of mTOR inhibitors}

Despite the promising efficacy of mTOR inhibitors in multiple clinical phenotypes associated with TSC, there is still a subset of patients who do not respond well to mTOR inhibitors. Therefore, studies have been conducted to explore the indicators based on predictive value to screen and identify patients who may benefit from mTOR inhibitor therapy.

\section{Computed tomography (CT) value of AML}

In our previous study, we found that renal AML volume and baseline mean $\mathrm{CT}$ value were important factors affecting the short-term volume response of AML 
to mTOR inhibitors. Further, statistical analysis revealed that a high $\mathrm{CT}$ value $(\geq-7 \mathrm{Hu})$ may imply a better response [112]. AML with low CT value and large volume often has a very high fat count. Because fat is trapped in poorly perfused cells that become more ischemic following mTOR inhibitor therapy, the response is poor. However, any potentially dangerous epithelioid/vascular components contained within them do shrink. Therefore, we recommend mTOR inhibitor therapy for patients with renal AML who exhibited a high CT value.

\section{Vascular endothelial growth factor (VEGF)-D}

Studies have shown a significant correlation between the vascular growth-promoting cytokine VEGF-D and renal AML size. Both exhibited a similar decreasing trend during continuous rapamycin treatment $[77,79,80]$. Taken together with our previous finding that renal AML volume affects the response to mTOR inhibitors, it is reasonable to speculate that high serum VEGF-D levels may imply a better response to mTOR inhibitors. Additionally, it was found that serum VEGF-D levels were related to the severity of LAM. Patients with higher serum VEGF-D levels had more significant improvements in FEV1 and FVC after rapamycin treatment, and serum VEGF-D levels decreased with an improvement in lung function [113]. These results suggest that serum VEGF-D is a useful marker not only in predicting efficacy but also in monitoring the response during treatment with mTOR inhibitors.

\section{Genotype}

An increasing number of patients with TSC have undergone TSC1/TSC2 genetic testing since the presentation of the genetic diagnosis of TSC at the 2012 International Tuberous Sclerosis Complex Consensus Conference. In addition to the diagnostic value, increasing attention has been paid to genetic testing in guiding therapy. However, no apparent associations between genotype and treatment response were found in the EXIST-1 and EXIST-2 trials [114].

Currently, the management of TSC is systematic. The discovery of mTOR pathway upregulation in TSC represents a potential opportunity for the targeted therapeutic strategy to control TSC-associated manifestations. Existing clinical trials have demonstrated that many patients with TSC can benefit from mTOR inhibitor therapy. Despite this breakthrough, several problems remain to be resolved. First, tumors regrow after treatment discontinuation, which necessitates lifelong therapy. Hence, there is an urgent requirement for new therapies that can permanently kill tumor cells and eliminate the need for continuous therapy. Second, although some molecular markers have been found to predict treatment efficacy, other indicators should be explored from the point of precision therapy. Lastly, although the AEs of mTOR inhibitors are mostly mild, some severe AEs have been reported that deserve attention [115]. Alternatives are required for patients who do not tolerate mTOR inhibitors.

\section{Conclusion}

mTOR inhibitors are effective in controlling TSC-associated clinical manifestations, implying a bright future for patients with TSC. Although several issues exist, we can be optimistic that better therapeutic strategies are underway.

\section{Acknowledgements \\ We thank several anonymous reviewers for their help with article quality improvement.}

\section{Authors' contributions}

$\mathrm{CL}, \mathrm{WRY}$ and $\mathrm{CY}$ participated in its design, coordination and drafted the manuscript. WS, PY, CC, YBH, MFC and XBZ conceived of the study, and participated in its design and coordination and helped to edit the manuscript. All authors read and approved the final manuscript.

\section{Funding}

This research was supported by the National Natural Science Foundation of China (81800590), the key Research and Development program of Hunan Province (2021SK2014) and National Natural Science Foundation of Hunan Province (2020JJ5882)

Availability of data and materials Not applicable.

\section{Declarations}

Ethics approval and consent to participate Not applicable.

\section{Consent for publication}

Not applicable.

\section{Competing interests}

The authors have nothing to disclose.

\section{Author details}

${ }^{1}$ Department of Urology, Disorders of Tuberous Sclerosis Complex (TSC) Multidisciplinary Team, National Clinical Research Center for Geriatric Disorders, Xiangya Hospital, Central South University, Changsha City 410008 , Hunan Province, People's Republic of China. ${ }^{2}$ Department of Neurosurgery, Xiangya Hospital, Central South University, No. 87 Xiangya Road, Changsha City 410008, Hunan Province, People's Republic of China. ${ }^{3}$ Department of Dermatology, Disorders of Tuberous Sclerosis Complex (TSC) Multidisciplinary Team, Xiangya Hospital, Central South University, No. 87 Xiangya Road, Changsha City 410008, Hunan Province, People's Republic of China. ${ }^{4}$ Department of Oral and Maxillofacial Surgery, Center of Stomatology, Disorders of Tuberous Sclerosis Complex (TSC) Multidisciplinary Team, Xiangya Hospital, Central South University, No. 87 Xiangya Road, Changsha City 410008, Hunan Province, People's Republic of China. ${ }^{5}$ Department of Pediatrics, Disorders of Tuberous Sclerosis Complex (TSC) Multidisciplinary Team, National Clinical Research Center for Geriatric Disorders, Xiangya Hospital, Central South University, No. 87 Xiangya Road, Changsha City 410008, Hunan Province, People's Republic of China. 
Received: 27 November 2021 Accepted: 20 February 2022 Published online: 04 March 2022

\section{References}

1. Osborne JP, Fryer A, Webb D. Epidemiology of tuberous sclerosis. Ann N Y Acad Sci. 1991;615:125-7. https://doi.org/10.1111/j.1749-6632.1991. tb37754.x.

2. Holmes GL, Stafstrom CE. Tuberous sclerosis complex and epilepsy: recent developments and future challenges. Epilepsia. 2007:48(4):61730. https://doi.org/10.1111/j.1528-1167.2007.01035.x.

3. Henske EP, Jóźwiak S, Kingswood JC, Sampson JR, Thiele EA. Tuberous sclerosis complex. Nat Rev Dis Primers. 2016;2:16035. https://doi.org/10. 1038/nrdp.2016.35.

4. de Vries PJ, Whittemore VH, Leclezio L, Byars AW, Dunn D, Ess KC, et al. Tuberous sclerosis associated neuropsychiatric disorders (TAND) and the TAND Checklist. Pediatr Neurol. 2015;52(1):25-35. https://doi.org/10. 1016/j.pediatrneurol.2014.10.004.

5. Henske EP, McCormack FX. Lymphangioleiomyomatosis-a wolf in sheep's clothing. J Clin Investig. 2012;122(11):3807-16. https://doi.org/ 10.1172/jci58709.

6. Gupta N, Henske EP. Pulmonary manifestations in tuberous sclerosis complex. Am J Med Genet C Semin Med Genet. 2018;178(3):326-37. https://doi.org/10.1002/ajmg.c.31638.

7. Sugalska M, Tomik A, Jóźwiak S, Werner B. Treatment of cardiac rhabdomyomas with mTOR inhibitors in children with tuberous sclerosis complex_a systematic review. Int J Environ Res Public Health. 2021. https://doi.org/10.3390/ijerph18094907.

8. Bernstein J, Robbins TO. Renal involvement in tuberous sclerosis. Ann N Y Acad Sci. 1991;615:36-49. https://doi.org/10.1111/j.1749-6632.1991. tb37746.x.

9. Bissler JJ, Kingswood JC. Renal angiomyolipomata. Kidney Int. 2004;66(3):924-34. https://doi.org/10.1111/j.1523-1755.2004.00838.x.

10. Rakowski SK, Winterkorn EB, Paul E, Steele DJ, Halpern EF, Thiele EA. Renal manifestations of tuberous sclerosis complex: Incidence, prognosis, and predictive factors. Kidney Int. 2006;70(10):1777-82. https://doi. org/10.1038/sj.ki.5001853.

11. Sampson JR, Maheshwar MM, Aspinwall R, Thompson P, Cheadle JP, Ravine D, et al. Renal cystic disease in tuberous sclerosis: role of the polycystic kidney disease 1 gene. Am J Hum Genet. 1997;61(4):843-51. https://doi.org/10.1086/514888.

12. Bjornsson J, Short MP, Kwiatkowski DJ, Henske EP. Tuberous sclerosisassociated renal cell carcinoma. Clinical, pathological, and genetic features. Am J Pathol. 1996;149(4):1201-8.

13. Teng JM, Cowen EW, Wataya-Kaneda M, Gosnell ES, Witman PM, Hebert AA, et al. Dermatologic and dental aspects of the 2012 International Tuberous Sclerosis Complex Consensus Statements. JAMA Dermatol. 2014;150(10):1095-101. https://doi.org/10.1001/jamadermatol.2014. 938.

14. Samueli S, Abraham K, Dressler A, Groeppel G, Jonak C, Muehlebner A, et al. Tuberous Sclerosis Complex: new criteria for diagnostic work-up and management. Wien Klin Wochenschr. 2015;127(15-16):619-30. https://doi.org/10.1007/s00508-015-0758-y.

15. Kingswood JC, Belousova E, Benedik MP, Budde K, Carter T, Cottin $V$, et al. TuberOus SClerosis registry to increAse disease awareness (TOSCA) Post-Authorisation Safety Study of Everolimus in Patients With Tuberous Sclerosis Complex. Front Neurol. 2021;12: 630378. https://doi. org/10.3389/fneur.2021.630378.

16. Xu L, Sterner C, Maheshwar MM, Wilson PJ, Nellist M, Short PM, et al. Alternative splicing of the tuberous sclerosis 2 (TSC2) gene in human and mouse tissues. Genomics. 1995;27(3):475-80. https://doi.org/10. 1006/geno.1995.1079.

17. Identification and characterization of the tuberous sclerosis gene on chromosome 16. Cell. 1993;75(7):1305-15.https://doi.org/10.1016/ 0092-8674(93)90618-z

18. Kwiatkowski DJ, Manning BD. Molecular basis of giant cells in tuberous sclerosis complex. N Engl J Med. 2014;371(8):778-80. https://doi.org/10. 1056/NEJMcibr1406613.
19. Dibble CC, Cantley LC. Regulation of mTORC1 by PI3K signaling. Trends Cell Biol. 2015;25(9):545-55. https://doi.org/10.1016/j.tcb.2015.06.002.

20. Crino PB, Nathanson $\mathrm{KL}$, Henske EP. The tuberous sclerosis complex. N Engl J Med. 2006;355(13):1345-56. https://doi.org/10.1056/NEJMra0553 23.

21. Huang J, Manning BD. The TSC1-TSC2 complex: a molecular switchboard controlling cell growth. Biochem J. 2008;412(2):179-90. https:// doi.org/10.1042/bj20080281.

22. Manning BD, Tee AR, Logsdon MN, Blenis J, Cantley LC. Identification of the tuberous sclerosis complex-2 tumor suppressor gene product tuberin as a target of the phosphoinositide 3-kinase/akt pathway. Mol Cell. 2002;10(1):151-62. https://doi.org/10.1016/s1097-2765(02) 00568-3.

23. Ma L, Chen Z, Erdjument-Bromage H, Tempst P, Pandolfi PP. Phosphorylation and functional inactivation of TSC 2 by Erk implications for tuberous sclerosis and cancer pathogenesis. Cell. 2005;121(2):179-93. https://doi.org/10.1016/j.cell.2005.02.031

24. Curatolo P, Bombardieri R, Jozwiak S. Tuberous sclerosis. Lancet. 2008;372(9639):657-68. https://doi.org/10.1016/s0140-6736(08) 61279-9.

25. El-Hashemite N, Zhang H, Henske EP, Kwiatkowski DJ. Mutation in TSC2 and activation of mammalian target of rapamycin signalling pathway in renal angiomyolipoma. Lancet. 2003;361(9366):1348-9. https://doi.org/ 10.1016/s0140-6736(03)13044-9.

26. Goncharova EA, Goncharov DA, Eszterhas A, Hunter DS, Glassberg MK, Yeung RS, et al. Tuberin regulates p70 S6 kinase activation and ribosomal protein S6 phosphorylation. A role for the TSC2 tumor suppressor gene in pulmonary lymphangioleiomyomatosis (LAM). J Biol Chem. 2002;277(34):30958-67. https://doi.org/10.1074/jbc.M202678200.

27. Musa J, Orth MF, Dallmayer M, Baldauf M, Pardo C, Rotblat B, et al. Eukaryotic initiation factor 4E-binding protein 1 (4E-BP1): a master regulator of mRNA translation involved in tumorigenesis. Oncogene. 2016:35(36):4675-88. https://doi.org/10.1038/onc.2015.515.

28. Zhang Y, Gao X, Saucedo LJ, Ru B, Edgar BA, Pan D. Rheb is a direct target of the tuberous sclerosis tumour suppressor proteins. Nat Cell Biol. 2003;5(6):578-81. https://doi.org/10.1038/ncb999.

29. Saxton RA, Sabatini DM. mTOR signaling in growth, metabolism, and disease. Cell. 2017;168(6):960-76. https://doi.org/10.1016/j.cell.2017.02. 004.

30. Jossin Y, Goffinet AM. Reelin signals through phosphatidylinositol 3-kinase and Akt to control cortical development and through mTor to regulate dendritic growth. Mol Cell Biol. 2007;27(20):7113-24. https:// doi.org/10.1128/mcb.00928-07.

31. Chévere-Torres I, Kaphzan H, Bhattacharya A, Kang A, Maki JM, Gambello MJ, et al. Metabotropic glutamate receptor-dependent long-term depression is impaired due to elevated ERK signaling in the $\triangle R G$ mouse model of tuberous sclerosis complex. Neurobiol Dis. 2012;45(3):110110. https://doi.org/10.1016/j.nbd.2011.12.028.

32. Hou L, Klann E. Activation of the phosphoinositide 3-kinase-Aktmammalian target of rapamycin signaling pathway is required for metabotropic glutamate receptor-dependent long-term depression. J Neurosci. 2004;24(28):6352-61. https://doi.org/10.1523/jneurosci.099504.2004.

33. Tavazoie SF, Alvarez VA, Ridenour DA, Kwiatkowski DJ, Sabatini BL. Regulation of neuronal morphology and function by the tumor suppressors Tsc1 and Tsc2. Nat Neurosci. 2005;8(12):1727-34. https://doi.org/10. 1038/nn1566.

34. Feliciano DM, Lin TV, Hartman NW, Bartley CM, Kubera C, Hsieh L, et al. A circuitry and biochemical basis for tuberous sclerosis symptoms: from epilepsy to neurocognitive deficits. Int J Dev Neurosci. 2013;31(7):66778. https://doi.org/10.1016/j.ijdevneu.2013.02.008.

35. Kelleher RJ 3rd, Bear MF. The autistic neuron: Troubled translation? Cell. 2008;135(3):401-6. https://doi.org/10.1016/j.cell.2008.10.017.

36. Santini E, Klann E. Reciprocal signaling between translational control pathways and synaptic proteins in autism spectrum disorders. Sci Signal. 2014:7(349):re10. https://doi.org/10.1126/scisignal.2005832.

37. Zeng LH, Ouyang Y, Gazit V, Cirrito JR, Jansen LA, Ess KC, et al. Abnormal glutamate homeostasis and impaired synaptic plasticity and learning in a mouse model of tuberous sclerosis complex. Neurobiol Dis. 2007:28(2):184-96. https://doi.org/10.1016/j.nbd.2007.07.015. 
38. Bateup HS, Johnson CA, Denefrio CL, Saulnier JL, Kornacker K, Sabatini BL. Excitatory/inhibitory synaptic imbalance leads to hippocampal hyperexcitability in mouse models of tuberous sclerosis. Neuron. 2013;78(3):510-22. https://doi.org/10.1016/j.neuron.2013.03.017.

39. Curatolo P. Mechanistic target of rapamycin (mTOR) in tuberous sclerosis complex-associated epilepsy. Pediatr Neurol. 2015;52(3):281-9. https://doi.org/10.1016/j.pediatrneurol.2014.10.028.

40. Jóźwiak J, Galus R. Molecular implications of skin lesions in tuberous sclerosis. Am J Dermatopathol. 2008;30(3):256-61. https://doi.org/10. 1097/DAD.0b013e31816e22a5.

41. Ho H, Kapadia R, Al-Tahan S, Ahmad S, Ganesan AK. WIPI1 coordinates melanogenic gene transcription and melanosome formation via TORC1 inhibition. J Biol Chem. 2011;286(14):12509-23. https://doi.org/10.1074/ jbc.M110.200543.

42. Vézina C, Kudelski A, Sehgal SN. Rapamycin (AY-22,989), a new antifungal antibiotic. I. Taxonomy of the producing streptomycete and isolation of the active principle. J Antibiot (Tokyo). 1975;28(10):721-6. https://doi.org/10.7164/antibiotics.28.721.

43. Franz DN, Krueger DA. mTOR inhibitor therapy as a disease modifying therapy for tuberous sclerosis complex. Am J Med Genet C Semin Med Genet. 2018;178(3):365-73. https://doi.org/10.1002/ajmg.c.31655.

44. Mahalati K, Kahan BD. Clinical pharmacokinetics of sirolimus. Clin Pharmacokinet. 2001;40(8):573-85. https://doi.org/10.2165/00003088200140080-00002.

45. Kirchner Gl, Meier-Wiedenbach I, Manns MP. Clinical pharmacokinetics of everolimus. Clin Pharmacokinet. 2004;43(2):83-95. https://doi.org/10. 2165/00003088-200443020-00002.

46. Faivre S, Kroemer G, Raymond E. Current development of mTOR inhibitors as anticancer agents. Nat Rev Drug Discov. 2006;5(8):671-88. https://doi.org/10.1038/nrd2062

47. Medvetz D, Priolo C, Henske EP. Therapeutic targeting of cellular metabolism in cells with hyperactive mTORC1: a paradigm shift. Mol Cancer Res. 2015;13(1):3-8. https://doi.org/10.1158/1541-7786.Mcr-14-0343.

48. Franz DN, Leonard J, Tudor C, Chuck G, Care M, Sethuraman G, et al. Rapamycin causes regression of astrocytomas in tuberous sclerosis complex. Ann Neurol. 2006;59(3):490-8. https://doi.org/10.1002/ana. 20784.

49. Krueger DA, Care MM, Holland K, Agricola K, Tudor C, Mangeshkar P, et al. Everolimus for subependymal giant-cell astrocytomas in tuberous sclerosis. N Engl J Med. 2010;363(19):1801-11. https://doi.org/10.1056/ NEJMoa1001671.

50. Franz DN, Belousova E, Sparagana S, Bebin EM, Frost M, Kuperman R, et al. Efficacy and safety of everolimus for subependymal giant cell astrocytomas associated with tuberous sclerosis complex (EXIST-1): a multicentre, randomised, placebo-controlled phase 3 trial. Lancet. 2013;381(9861):125-32. https://doi.org/10.1016/s0140-6736(12) 61134-9.

51. Franz DN, Belousova E, Sparagana S, Bebin EM, Frost M, Kuperman R, et al. Everolimus for subependymal giant cell astrocytoma in patients with tuberous sclerosis complex: 2-year open-label extension of the randomised EXIST-1 study. Lancet Oncol. 2014;15(13):1513-20. https:// doi.org/10.1016/s1470-2045(14)70489-9.

52. Franz DN, Agricola K, Mays M, Tudor C, Care MM, Holland-Bouley K, et al. Everolimus for subependymal giant cell astrocytoma: 5-year final analysis. Ann Neurol. 2015;78(6):929-38. https://doi.org/10.1002/ana. 24523.

53. Shehata HS, AbdelGhaffar HM, Nasreldin M, Elmazny A, Abdelalim A, Sabbah A, et al. Clinical patterns and outcomes of status epilepticus in patients with tuberous sclerosis complex. Ther Clin Risk Manag. 2017;13:779-85. https://doi.org/10.2147/tcrm.S138576.

54. Krueger DA, Wilfong AA, Holland-Bouley K, Anderson AE, Agricola K, Tudor $C$, et al. Everolimus treatment of refractory epilepsy in tuberous sclerosis complex. Ann Neurol. 2013;74(5):679-87. https://doi.org/10. 1002/ana.23960.

55. French JA, Lawson JA, Yapici Z, Ikeda H, Polster T, Nabbout R, et al. Adjunctive everolimus therapy for treatment-resistant focal-onset seizures associated with tuberous sclerosis (EXIST-3): a phase 3, randomised, double-blind, placebo-controlled study. Lancet. 2016;388(10056):2153-63. https://doi.org/10.1016/s0140-6736(16) 31419-2.
56. Overwater IE, Rietman AB, Bindels-de Heus K, Looman CW, Rizopoulos D, Sibindi TM, et al. Sirolimus for epilepsy in children with tuberous sclerosis complex: a randomized controlled trial. Neurology. 2016;87(10):1011-8. https://doi.org/10.1212/wnl.0000000000003077.

57. He W, Chen J, Wang YY, Zhang MN, Qian L, Wang QH, et al. Sirolimus improves seizure control in pediatric patients with tuberous sclerosis: a prospective cohort study. Seizure. 2020;79:20-6. https://doi.org/10. 1016/j.seizure.2020.03.018.

58. Karadag D, Mentzel HJ, Güllmar D, Rating T, Löbel U, Brandl U, et al. Diffusion tensor imaging in children and adolescents with tuberous sclerosis. Pediatr Radiol. 2005;35(10):980-3. https://doi.org/10.1007/ s00247-005-1504-9.

59. Chandra PS, Salamon N, Huang J, Wu JY, Koh S, Vinters HV, et al. FDG-PET/MRI coregistration and diffusion-tensor imaging distinguish epileptogenic tubers and cortex in patients with tuberous sclerosis complex: a preliminary report. Epilepsia. 2006;47(9):1543-9. https:// doi.org/10.1111/j.1528-1167.2006.00627.x.

60. Widjaja E, Simao G, Mahmoodabadi SZ, Ochi A, Snead OC, Rutka J, et al. Diffusion tensor imaging identifies changes in normal-appearing white matter within the epileptogenic zone in tuberous sclerosis complex. Epilepsy Res. 2010;89(2-3):246-53. https://doi.org/10. 1016/j.eplepsyres.2010.01.008.

61. Tillema JM, Leach $J$, Krueger DA, Franz DN. Everolimus alters white matter diffusion in tuberous sclerosis complex. Neurology. 2012;78(8):526-31. https://doi.org/10.1212/WNL.0b013e318247ca8d.

62. Krueger DA, Sadhwani A, Byars AW, de Vries PJ, Franz DN, Whittemore $\mathrm{VH}$, et al. Everolimus for treatment of tuberous sclerosis complexassociated neuropsychiatric disorders. Ann Clin Transl Neurol. 2017;4(12):877-87. https://doi.org/10.1002/acn3.494.

63. Overwater IE, Rietman AB, Mous SE, Bindels-de Heus K, Rizopoulos D, Ten Hoopen LW, et al. A randomized controlled trial with everolimus for IQ and autism in tuberous sclerosis complex. Neurology. 2019;93(2):e200-9. https://doi.org/10.1212/wnl.0000000000007749.

64. Bissler JJ, McCormack FX, Young LR, Elwing JM, Chuck G, Leonard JM, et al. Sirolimus for angiomyolipoma in tuberous sclerosis complex or lymphangioleiomyomatosis. N Engl J Med. 2008;358(2):140-51. https://doi.org/10.1056/NEJMoa063564.

65. McCormack FX, Inoue Y, Moss J, Singer LG, Strange C, Nakata K, et al. Efficacy and safety of sirolimus in lymphangioleiomyomatosis. N Engl J Med. 2011;364(17):1595-606. https://doi.org/10.1056/NEJMoa1 100 391.

66. Taveira-DaSilva AM, Hathaway O, Stylianou M, Moss J. Changes in lung function and chylous effusions in patients with lymphangioleiomyomatosis treated with sirolimus. Ann Intern Med. 2011;154(12):797-805, w-292-3. https://doi.org/10.7326/0003-4819154-12-201106210-00007

67. Goldberg HJ, Harari S, Cottin V, Rosas IO, Peters E, Biswal S, et al. Everolimus for the treatment of lymphangioleiomyomatosis: a phase II study. Eur Respir J. 2015;46(3):783-94. https://doi.org/10.1183/09031936. 00210714.

68. Lim KH, Silverstone EJ, Yates DH. Multifocal micronodular pneumocyte hyperplasia in tuberous sclerosis complex: resolution with everolimus treatment. Am J Respir Crit Care Med. 2020;201(10): e76. https://doi. org/10.1164/rccm.201907-1302IM.

69. Mlczoch E, Hanslik A, Luckner D, Kitzmüller E, Prayer D, Michel-Behnke I. Prenatal diagnosis of giant cardiac rhabdomyoma in tuberous sclerosis complex: a new therapeutic option with everolimus. Ultrasound Obstet Gynecol. 2015;45(5):618-21. https://doi.org/10.1002/uog.13434.

70. Dahdah N. Everolimus for the treatment of tuberous sclerosis complex-related cardiac rhabdomyomas in pediatric patients. J Pediatr. 2017;190:21-6.e7. https://doi.org/10.1016/j.jpeds.2017.06.076.

71. Krueger DA, Northrup H. Tuberous sclerosis complex surveillance and management: recommendations of the 2012 International Tuberous Sclerosis Complex Consensus Conference. Pediatr Neurol. 2013;49(4):255-65. https://doi.org/10.1016/j.pediatrneurol.2013.08.002.

72. Eijkemans MJ, van der Wal W, Reijnders LJ, Roes KC, van Waalwijk van Doorn-Khosrovani SB, Pelletier C, et al. Long-term follow-up assessing renal angiomyolipoma treatment patterns, morbidity, and mortality: an observational study in Tuberous Sclerosis Complex Patients in the Netherlands. Am J Kidney Dis. 2015;66(4):638-45. https://doi.org/10. 1053/j.ajkd.2015.05.016 
73. Kessler OJ, Gillon G, Neuman M, Engelstein D, Winkler H, Baniel J. Management of renal angiomyolipoma: analysis of 15 cases. Eur Urol. 1998;33(6):572-5. https://doi.org/10.1159/000019658.

74. Kothary N, Soulen MC, ClarkTW, Wein AJ, Shlansky-Goldberg RD, Crino $\mathrm{PB}$, et al. Renal angiomyolipoma: long-term results after arterial embolization. J Vasc Interv Radiol. 2005;16(1):45-50. https://doi.org/10.1097/ 01.Rvi.0000143769.79774.70.

75. Wienecke R, Fackler I, Linsenmaier U, Mayer K, Licht T, Kretzler M. Antitumoral activity of rapamycin in renal angiomyolipoma associated with tuberous sclerosis complex. Am J Kidney Dis. 2006;48(3):e27-9. https:// doi.org/10.1053/j.ajkd.2006.05.018.

76. Davies DM, de Vries PJ, Johnson SR, McCartney DL, Cox JA, Serra AL, et al. Sirolimus therapy for angiomyolipoma in tuberous sclerosis and sporadic lymphangioleiomyomatosis: a phase 2 trial. Clin Cancer Res. 2011;17(12):4071-81. https://doi.org/10.1158/1078-0432.Ccr-11-0445.

77. Dabora SL, Franz DN, Ashwal S, Sagalowsky A, DiMario FJ Jr, Miles $D$, et al. Multicenter phase 2 trial of sirolimus for tuberous sclerosis: kidney angiomyolipomas and other tumors regress and VEGF- D levels decrease. PLoS ONE. 2011;6(9): e23379. https://doi.org/10.1371/journal. pone.0023379.

78. Cabrera-López C, Martí T, Catalá V, Torres F, Mateu S, Ballarín J, et al. Assessing the effectiveness of rapamycin on angiomyolipoma in tuberous sclerosis: a two years trial. Orphanet J Rare Dis. 2012;7:87. https:// doi.org/10.1186/1750-1172-7-87.

79. Malinowska IA, Lee N, Kumar V, Thiele EA, Franz DN, Ashwal S, et al. Similar trends in serum VEGF-D levels and kidney angiomyolipoma responses with longer duration sirolimus treatment in adults with tuberous sclerosis. PLoS ONE. 2013;8(2): e56199. https://doi.org/10. 1371/journal.pone.0056199.

80. Bissler JJ, Kingswood JC, Radzikowska E, Zonnenberg BA, Frost M, Belousova $\mathrm{E}$, et al. Everolimus for angiomyolipoma associated with tuberous sclerosis complex or sporadic lymphangioleiomyomatosis (EXIST-2): a multicentre, randomised, double-blind, placebo-controlled trial. Lancet. 2013;381(9869):817-24. https://doi.org/10.1016/s01406736(12)61767-X

81. Ni J, Yan F, Qin W, Yu L, Zhang G, Liu F, et al. Mutational analysis of renal angiomyolipoma associated with tuberous sclerosis complex and the outcome of short-term everolimus therapy. Sci Rep. 2019;9(1):14337. https://doi.org/10.1038/s41598-019-49814-6.

82. Bissler JJ, Franz DN, Frost MD, Belousova E, Bebin EM, Sparagana S, et al. The effect of everolimus on renal angiomyolipoma in pediatric patients with tuberous sclerosis being treated for subependymal giant cell astrocytoma. Pediatr Nephrol. 2018;33(1):101-9. https://doi.org/10. 1007/s00467-017-3806-1.

83. Consugar MB, Wong WC, Lundquist PA, Rossetti S, Kubly VJ, Walker DL, et al. Characterization of large rearrangements in autosomal dominant polycystic kidney disease and the PKD1/TSC2 contiguous gene syndrome. Kidney Int. 2008;74(11):1468-79. https://doi.org/10.1038/ki. 2008.485 .

84. Siroky BJ, Towbin AJ, Trout AT, Schäfer H, Thamann AR, Agricola KD, et al. Improvement in renal cystic disease of tuberous sclerosis complex after treatment with mammalian target of rapamycin inhibitor. J Pediatr. 2017;187:318-22.e2. https://doi.org/10.1016/j.jpeds.2017.05.015.

85. Alsidawi S, Kasi PM. Exceptional response to everolimus in a novel tuberous sclerosis complex-2 mutation-associated metastatic renal-cell carcinoma. Cold Spring Harb Mol Case Stud. 2018. https://doi.org/10. 1101/mcs.a002220.

86. Bittencourt RC, Huilgol SC, Seed PT, Calonje E, Markey AC, Barlow RJ. Treatment of angiofibromas with a scanning carbon dioxide laser: a clinicopathologic study with long-term follow-up. J Am Acad Dermatol. 2001;45(5):731-5. https://doi.org/10.1067/mjd.2001.116223.

87. El-Musa KA, Shehadi RS, Shehadi S. Extensive facial adenoma sebaceum: successful treatment with mechanical dermabrasion: case report. Br J Plast Surg. 2005;58(8):1143-7. https://doi.org/10.1016/j.bjps. 2005.04.021.

88. Papadavid E, Markey A, Bellaney G, Walker NP. Carbon dioxide and pulsed dye laser treatment of angiofibromas in 29 patients with tuberous sclerosis. Br J Dermatol. 2002;147(2):337-42. https://doi.org/10. 1046/j.1365-2133.2002.04968.x.

89. Franz DN, Budde K, Kingswood JC, Belousova E, Sparagana S, de Vries PJ, et al. Effect of everolimus on skin lesions in patients treated for subependymal giant cell astrocytoma and renal angiomyolipoma: final 4-year results from the randomized EXIST-1 and EXIST-2 studies. J Eur Acad Dermatol Venereol. 2018;32(10):1796-803. https://doi.org/10. 1111/jdv.14964.

90. Koenig MK, Hebert AA, Roberson J, Samuels J, Slopis J, Woerner A, et al. Topical rapamycin therapy to alleviate the cutaneous manifestations of tuberous sclerosis complex: a double-blind, randomized, controlled trial to evaluate the safety and efficacy of topically applied rapamycin. Drugs R D. 2012;12(3):121-6. https://doi.org/10.2165/11634580-00000 0000-00000.

91. Tanaka M, Wataya-Kaneda M, Nakamura A, Matsumoto S, Katayama I. First left-right comparative study of topical rapamycin vs. vehicle for facial angiofibromas in patients with tuberous sclerosis complex. $\mathrm{Br} J$ Dermatol. 2013;169(6):1314-8. https://doi.org/10.1111/bjd.12567.

92. Wataya-Kaneda M, Nakamura A, Tanaka M, Hayashi M, Matsumoto S, Yamamoto K, et al. Efficacy and safety of topical sirolimus therapy for facial angiofibromas in the tuberous sclerosis complex : a randomized clinical trial. JAMA Dermatol. 2017;153(1):39-48. https://doi.org/10. 1001/jamadermatol.2016.3545.

93. Koenig MK, Bell CS, Hebert AA, Roberson J, Samuels JA, Slopis JM, et al. Efficacy and safety of topical rapamycin in patients with facial angiofibromas secondary to tuberous sclerosis complex: the TREATMENT randomized clinical trial. JAMA Dermatol. 2018;154(7):773-80. https:// doi.org/10.1001/jamadermatol.2018.0464.

94. Wataya-Kaneda M, Ohno Y, Fujita Y, Yokozeki H, Niizeki H, Ogai M, et al. Sirolimus gel treatment vs placebo for facial angiofibromas in patients with tuberous sclerosis complex: a randomized clinical trial. JAMA Dermatol. 2018;154(7):781-8. https://doi.org/10.1001/jamadermatol. 2018.1408.

95. Leducq S, Giraudeau B, Tavernier E, Maruani A. Topical use of mammalian target of rapamycin inhibitors in dermatology: a systematic review with meta-analysis. J Am Acad Dermatol. 2019;80(3):735-42. https://doi. org/10.1016/j.jaad.2018.10.070.

96. Lee Yl, Lee JH, Kim DY, Chung KY, Shin JU. Comparative effects of topical $0.2 \%$ sirolimus for angiofibromas in adults and pediatric patients with tuberous sclerosis complex. Dermatology. 2018;234(1-2):13-22. https:// doi.org/10.1159/000489089.

97. Norrenberg S, Masconi M, Karamanou M, Meylan P, Golaz R, ChristenZaech S. Retrospective study of rapamycin or rapalog $0 \cdot 1 \%$ cream for facial angiofibromas in tuberous sclerosis complex: evaluation of treatment effectiveness and cost. Br J Dermatol. 2018;179(1):208-9. https:// doi.org/10.1111/bjd.16397.

98. Chen PL, Hong JB, Shen LJ, Chen YT, Wang SJ, Liao YH. The efficacy and safety of topical rapamycin-calcitriol for facial angiofibromas in patients with tuberous sclerosis complex: a prospective, double-blind, randomized clinical trial. Br J Dermatol. 2020;183(4):655-63. https://doi. org/10.1111/bjd.18949.

99. Ohguchi K, Banno Y, Nakagawa Y, Akao Y, Nozawa Y. Negative regulation of melanogenesis by phospholipase D1 through mTOR/p70 S6 kinase 1 signaling in mouse B16 melanoma cells. J Cell Physiol. 2005;205(3):44451. https://doi.org/10.1002/jcp.20421.

100. Hah YS, Cho HY, Lim TY, Park DH, Kim HM, Yoon J, et al. Induction of melanogenesis by rapamycin in human MNT-1 melanoma cells. Ann Dermatol. 2012;24(2):151-7. https://doi.org/10.5021/ad.2012.24.2.151.

101. Wataya-Kaneda M, Tanaka M, Nakamura A, Matsumoto S, Katayama I. A novel application of topical rapamycin formulation, an inhibitor of mTOR, for patients with hypomelanotic macules in tuberous sclerosis complex. Arch Dermatol. 2012;148(1):138-9. https://doi.org/10.1001/ archderm.148.1.138.

102. Wataya-Kaneda M, Tanaka M, Yang L, Yang F, Tsuruta D, Nakamura A, et al. Clinical and histologic analysis of the efficacy of topical rapamycin therapy against hypomelanotic macules in tuberous sclerosis complex. JAMA Dermatol. 2015;151(7):722-30. https://doi.org/10.1001/jamad ermatol.2014.4298.

103. Rugo HS, Hortobagyi GN, Yao J, Pavel M, Ravaud A, Franz D, et al. Metaanalysis of stomatitis in clinical studies of everolimus: incidence and relationship with efficacy. Ann Oncol. 2016;27(3):519-25. https://doi. org/10.1093/annonc/mdv595.

104. Sadowski K, Kotulska K, Jóźwiak S. Management of side effects of mTOR inhibitors in tuberous sclerosis patients. Pharmacol Rep. 2016;68(3):536-42. https://doi.org/10.1016/j.pharep.2016.01.005. 
105. Curatolo P, Nabbout R, Lagae L, Aronica E, Ferreira JC, Feucht M, et al. Management of epilepsy associated with tuberous sclerosis complex: updated clinical recommendations. Eur J Paediatr Neurol. 2018;22(5):738-48. https://doi.org/10.1016/j.ejpn.2018.05.006.

106. Devinsky O, Vezzani A, O'Brien TJ, Jette N, Scheffer IE, de Curtis M, et al. Epilepsy. Nat Rev Dis Primers. 2018;4:18024. https://doi.org/10.1038/ nrdp.2018.24.

107. Sparagana S, Franz DN, Krueger DA, Bissler JJ, Berkowitz N, Burock K, et al. Pooled analysis of menstrual irregularities from three major clinical studies evaluating everolimus for the treatment of tuberous sclerosis complex. PLoS ONE. 2017;12(10): e0186235. https://doi.org/10.1371/ journal.pone.0186235.

108. Kraemer FB, Takeda D, Natu V, Sztalryd C. Insulin regulates lipoprotein lipase activity in rat adipose cells via wortmannin- and rapamycinsensitive pathways. Metabolism. 1998;47(5):555-9. https://doi.org/10. 1016/s0026-0495(98)90239-6.

109. Pirson Y. Tuberous sclerosis complex-associated kidney angiomyolipoma: from contemplation to action. Nephrol Dial Transplant. 2013;28(7):1680-5. https://doi.org/10.1093/ndt/gft009.

110. Bissler JJ, Budde K, Sauter M, Franz DN, Zonnenberg BA, Frost MD, et al. Effect of everolimus on renal function in patients with tuberous sclerosis complex: evidence from EXIST-1 and EXIST-2. Nephrol Dial Transplant. 2019;34(6):1000-8. https://doi.org/10.1093/ndt/gfy132.

111. Davies M, Saxena A, Kingswood JC. Management of everolimusassociated adverse events in patients with tuberous sclerosis complex: a practical guide. Orphanet J Rare Dis. 2017;12(1):35. https://doi.org/10. 1186/s13023-017-0581-9.

112. Wang W, Guo H, Shi B, Sun H, Li H, Zhang Y, et al. CT characteristics predict the response to everolimus or sirolimus of renal angiomyolipomas in patients with tuberous sclerosis complex. Int Urol Nephrol. 2019;51(4):671-6. https://doi.org/10.1007/s11255-019-02093-6.

113. Young L, Lee HS, Inoue Y, Moss J, Singer LG, Strange C, et al. Serum VEGF-D a concentration as a biomarker of lymphangioleiomyomatosis severity and treatment response: a prospective analysis of the Multicenter International Lymphangioleiomyomatosis Efficacy of Sirolimus (MILES) trial. Lancet Respir Med. 2013;1 (6):445-52. https://doi.org/10. 1016/s2213-2600(13)70090-0.

114. Kwiatkowski DJ, Palmer MR, Jozwiak S, Bissler J, Franz D, Segal S, et al. Response to everolimus is seen in TSC-associated SEGAs and angiomyolipomas independent of mutation type and site in TSC1 and TSC2. Eur J Hum Genet. 2015;23(12):1665-72. https://doi.org/10.1038/ejhg.2015. 47.

115. Trelinska J, Dachowska I, Kotulska K, Fendler W, Jozwiak S, Mlynarski W. Complications of mammalian target of rapamycin inhibitor anticancer treatment among patients with tuberous sclerosis complex are common and occasionally life-threatening. Anticancer Drugs. 2015;26(4):437-42. https://doi.org/10.1097/cad.0000000000000207.

\section{Publisher's Note}

Springer Nature remains neutral with regard to jurisdictional claims in published maps and institutional affiliations.

Ready to submit your research? Choose BMC and benefit from:

- fast, convenient online submission

- thorough peer review by experienced researchers in your field

- rapid publication on acceptance

- support for research data, including large and complex data types

- gold Open Access which fosters wider collaboration and increased citations

- maximum visibility for your research: over $100 \mathrm{M}$ website views per year

At BMC, research is always in progress.

Learn more biomedcentral.com/submissions 